\title{
Synthesis of Olodanrigan
}<smiles>CCCCOc1c(C=O)cccc1OC</smiles>

A

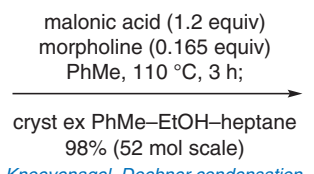
$98 \%$ (52 mol scale)
Knoevenagel-Doebner condensation

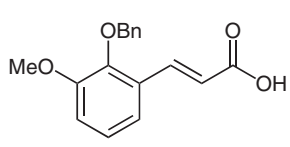

B white powder
mp not reported<smiles>CCCOc1c(OC)ccc2c1CC(C(=O)O[NH3+])N(C(=O)C(c1ccccc1)c1ccccc1)C2</smiles>
[G]* cryst ex $i-\mathrm{PrOH}-\mathrm{PhM}$ $90 \%$ from D<smiles>COC(=O)c1c(OC)ccc2c1C[C@H](C(=O)O)N(C(=O)C(c1ccccc1)c1ccccc1)C2</smiles>

$[\mathrm{F}]^{*}$<smiles>COc1ccc2c(c1OCc1ccccc1)CC(C(=O)O[NH2+][O-])N(C(=O)C(c1ccccc1)c1ccccc1)C2</smiles>

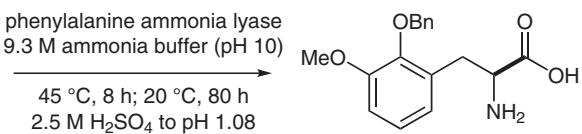

$[\mathrm{C}]^{\star}$

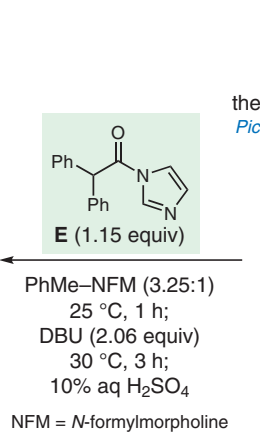

Category

Synthesis of Natural

Products and

Potential Drugs

\section{Key words}

olodanrigan

phenylalanine ammonia lyase

hydroamination

tetrahydroisoquinolines

Pictet-Spengler reaction
Significance: Olodanrigan (EMA401) is an angiotensin II type 2 antagonist that had been considered for the treatment of postherpetic neuralgia and neuropathic pain. This short synthesis of olodanrigan is presented in detail in three back-toback papers. Part 1 concerns the optimized conversion of the phenylalanine $\mathbf{C}$ to the target molecule and includes the search for a suitable polymorph. Part 2 (Org. Process Res. Dev. 2020, 24, 1756) concerns development of a pyridine- and piperidinefree Knoevenagel-Doebner condensation using a catalytic amount of morpholine that delivered $25 \mathrm{~kg}$ of cinnamic acid $\mathrm{C}$ in $98 \%$ yield.
Comment: Part 3 (Org. Process Res. Dev. 2020, 24, 1763) describes the hydroamination of the cinnamic acid B using an engineered phenylalanine ammonia lyase enzyme to afford amino acid C. Enzyme loadings as low as $2.5 \mathrm{wt} \%(\mathrm{E} / \mathrm{S}=1: 40 \mathrm{w} / \mathrm{w})$ and substrate concentrations between 1.17-0.39 M were compatible with the reaction conditions. The telescoped process from $\mathbf{B}$ via $\mathbf{C}$ to tetrahydroisoquinoline $\mathbf{D}$ was scaled up to a batch size of $2 \mathrm{~kg}$, resulting in $81 \%$ conversion to $\mathrm{C}$ and a $59 \%$ isolated yield of $\mathbf{D}$ with high chiral purity (er $=99.9: 0.1)$. 